\title{
INOVASI PEMBELAJARAN PENDIDIKAN AGAMA ISLAM BERBASIS BLENDED COOPERATIVE E LEARNING DI MASA PANDEMI
}

\section{Nur Irsyadiah dan Ahmad Rifa'i}

Universitas Islam Jakarta dan Kantor Kementerian Agama Kota Administrasi Jakarta

Pusat, Indonesia

Email: nurirsyadiah@uid.ac.id dan azka2thn@gmail.com

\section{Abstract}

The purpose of this research is to find pai learning strategies and ways by using blanded e cooperative e learning methods. The research method used is qualitative research method by observing directly the implementation ofdefensejaran jaurak far in muhammadiyah college branch senen jakarta pusat. The results showed that blanded cooperative e learning method is the ideal solution in dealing with pandemic covid 19. Because this method can bridge the gap between students who have technological means and who do not have them. The combination of cooperative learning and blended learning approaches not only equips students with the ability to understand the material, but more than that can improve communication skills and interpersonal skills, problem solving, critical analysis and other skills needed by students. With the ease of technology, the limitations of classroom meetings can be solved by blended learning.

Keywords: blended learning; islamic religious education learning

\begin{abstract}
Abstrak
Tujuan penelitian ini adalah untuk menemukan strategi dan cara pembelajaran PAI dengan menggunakan metode blanded e cooperative e learning. Adapun metode penelitian yang digunakan adalah metode penelitian kualitatif dengan mengamati langsung pelaksanaan pembelajaran jaurak jauh di perguruan muhammadiyah cabang senen jakarta pusat. Hasil penelitian menunjukkan bahwa metode blanded cooperative e learning adalah solusi ideal dalam menghadapi pandemi covid 19. Sebab metode ini dapat menjembatani kesenjangan antara peserta didik yang memiliki sarana teknologi dan yang tidak memilikinya. Perpaduan antara pendekatan pembelajaran cooperative learning dan blended learning tidak saja hanya membekali siswa kemampuan memahami materi, namun lebih dari itu dapat meningkatkan kemampuan komunikasi dan keterampilan interpersonal, pemecahan masalah, analisis kritis dan keterampilan lain yang dibutuhkan oleh siswa. Dengan kemudahan teknologi, keterbatasan pertemuan di kelas dapat dipecahkan dengan blended learning.
\end{abstract}

Kata kunci: blended learning; pendidikan agama islam; inovasi pembelajaran

\section{Pendahuluan}

Setiap negara di belahan dunia sekarang sedang menaruh perhatian penuh untuk mengatasi corona virus disease 2019 (Covid-19). Ini semua dikarenakan covid-19 yang 
telah menjadi pandemi bagi masyarakat di seluruh dunia dan sudah banyak menelan korban jiwa manusia (Bakri, 2020).

Coronavirus adalah sekumpulan virus dari subfamili Orthocronavirinae dalam keluarga Coronaviridae dan ordo Nidovirales. Kelompok virus ini yang dapat menyebabkan penyakit pada burung dan mamalia, termasuk manusia. Pada manusia, coronavirus menyebabkan infeksi saluran pernapasan yang umumnya ringan, seperti pilek, meskipun beberapa bentuk penyakit seperti; SARS, MERS, dan COVID-19 sifatnya lebih mematikan (Yunus \& Rezki, 2020).

Pemerintah pun mempunyai kendala yang sangat besar dalam mengatasi kendala ini karena menyangkut dengan persoalan ekonomi, sosial kesehatan, pendidikan, keamanan dan lain-lain dalam mengatasi covid-19 (Juliani, 2020). Maka di sini diperlukan kerjasama yang baik antara pemerintah dan warga masyarakat dalam rangka memutuskan mata rantai penyebaran covid-19 dalam skala besar dan luas sehingga virus ini tidak berdaya menyebar ke warga masyarakat lainnya, dengan menerapkan sistem ketaatan dan disiplin bagi warga itu sendiri.

Karena adanya virus ini, aktivitas masyarakat di berbagai Negara jadi terganggu sehingga membuat masyarakat di dunia harus tetap diam dirumah untuk memutus mata tantai virus corona agar tidak semakin menyebar. Lalu perekonomian di berbagai dunia juga semakin menurun karena adanya virus ini. Asian Development Bank (ADB) memprediksi pertumbuhan ekonomi nasional hanya sebesar 2,5\% pada tahun 2020 atau terpangkas setengahnya setelah pada tahun 2019 tumbuh 5,0\%. Hal ini disebabkan oleh pandemi virus corona yang menjangkiti berbagai wilayah nusantara (Siahaan, 2020).

Pemerintah telah melakukan upaya peningkatan kualitas dan kuantitas yang mengusung nama pendidikan. Salah satu upaya yang dilakukan oleh pemerintah biasanya bersifat konstitusional untuk mendapatkan lulusan dari sekolah yang kompetitif dan siap bersaing secara global (Pujilestari, 2020).

Dilema ini juga berimbas ke dalam dunia pendidikan walaupun sudah ada sebuah regulasi baru yang di keluarkan oleh pemerintah, dengan pembatasan kegiatan di setiap satuan pendidikan. Dengan sistem proses belajar mengajar di satuan pendidikan wajib mematuhi dan menaati oleh setiap warga dari satuan pendidikan di seluruh Indonesia khususnya, tetapi ini bukan berarti guru dan siswa hanya bebas belajar (Yaumi, 2017).

Era reformasi ditandai dengan tergulingnya rezim pemerintahan Soeharto, dibarengi dengan krisis moneter, ekonomi, dan politik telah mendorong arus pem baruan dalam semua aspek kehidupan. Pembaruan dan reformasi telah menggerakkan perubahan dalam semua aspek kehidupan, bahkan berdampak pada euforia kebebasan yang nyaris kebablasan (Setiani, Nivanty, Lutfiah, \& Rahmawati, 2020).

Guru dan siswa tetap harus melaksanakan pembelajaran di rumah masing-masing dengan metode daring (dalam jaringan), metode luring (jaringan luar) atau dengan media lainnya yang bisa mengakses model pembelajaran sesuai dengan aturan protokol di satuan pendidikan masing-masing (Suhendro, 2020).

Kebijakan pembelajaran melalui metode daring merupakan sebuah manfaat yang sangat besar bagi siswa di era teknologi digital, sehingga dapat memberi hak-hak otonomi bagi siswa agar proses belajar tetap berjalan, meskipun dalam kondisi yang 
sangat prihatin dalam menghadapi darurat pandemi covid-19. Namun demikian, masih banyak kendala yang dihadapi guru dan siswa yang muncul dalam pembelajaran metode daring yang tidak bisa dihindari (Sanjaya, 2020).

Sebagaimana contoh, yang akan terjadi di satuan pendidikan atau daerah 3T (daerah tertinggal, terdepan, dan terluar) yang terkendala dengan koneksi jaringan internet yang tidak ada, tentu ini tidak bisa dilaksanakan dengan sistem daring ataupun media teknologi lainnya. Karena kemajuan informasi dan komunikasi, karena keterbatasan pemerataan teknologi sehingga bagi mereka belum bisa dan sulit melaksanakan pembelajaran daring ataupun dengan media lainya.

Alasan lain yang muncul adalah masih banyaknya satuan pendidikan yang belum familiar dengan perkembangan informasi dan komunikasi sehingga beberapa platform pembelajaran daring yang dapat digunakan dalam pembelajaran daring.

Pembelajaran pendidikan agama islam di sekolah-sekolah terus mengalami perkembangan sesuai dengan kondisi dan kemampuan siswa masing-masing. Akan tetapi berdasarkan pengamatan riil di lapangan metode yang digunakan masih bersifat monoton dan bersifat teacher centre. Akibatnya adalah siswa sering merasa bosan dan kurang bersemangat dalam mengikuti pelajaran tersebut (Syaparuddin, Meldianus, \& Elihami, 2020).

Guru Pendidikan Agama Islam (PAI) dan Budi Pekerti merupakan komponen paling menentukan dalam sistem pendidikan dan pembelajaran secara keseluruhan pada satuan pendidikan. Hal ini karena guru PAI dan Budi Pekerti sangat menentukan keberhasilan peserta didik terutama dalam kaitannya dengan pembentukan kepribadian dan akhlak mulia serta pencapaian tujuan pembelajaran (Wahidin, 2018).

Untuk menciptakan pembelajaran yang menyenangkan, aktif, kreatif dan inovatif dibutuhkan keterampilan dan keahlian para guru dalam mengembangkan pembelajaran. Guru tidak hanya mengajarkan apa yang ada dalam buku semata namun juga mampu mengimplementasikan pengalaman dan pengetahuannya dalam pembelajaran tersebut (Saefudin, 2008).

Pandemi covid-19 telah memberikan gambaran atas kelangsungan dunia pendidikan di masa depan melalui bantuan teknologi. Namun, teknologi tetap tidak dapat menggantikan peran guru, dosen, dan interaksi belajar antara pelajar dan pengajar sebab edukasi bukan hanya sekedar memperoleh pengetahuan tetapi juga tentang nilai, kerja sama, serta kompetensi. Situasi pandemi ini menjadi tantangan tersendiri bagi kreativitas setiap individu dalam menggunakan teknologi untuk mengembangkan dunia Pendidikan (Simarmata et al., 2020).

Tugas guru adalah membimbing, mendampingi dan mengarahkan peserta didik dalam belajar. Maka diperlukan guru yang berjiwa inovatif dan kreatif sehingga dapat menciptakan suasana belajar yang berkualitas. Adapun penerapan yang dilakukan selain dengan e-learning yaitu dengan blended learning. Blended learning adalah sebuah kemudahan pembelaiaran yang menggabungkan berbagai pembelajaran. memperkenalkan berbagai pilihan media dialog antara fasilitator dengan individu yang mendapat pengajaran. Menurut (Harding, Kaczynski, \& Wood, 2012) blended learning 
juga sebagai sebuah kombinasi pengajaran langsung (face-to-face's) dan pengajaran online, tapi lebih daripada ltu sebagai elemen dan interaksi social.

Secara terperinci blended learning merupakan pendekatan pembelajaran yang mengintegrasikan pembelajaran tradisonal tatap muka dan pembelajaran jarak jauh yang menggunakan sumber belajar online dan beragam pilihan komunikasi yang dapat digunakan oleh pendidik dan peserta didik (Rusdiana, Sulhan, Arifin, \& Kamaludin, 2020).

Dalam tulisan ini, akan dipaparkan dengan jelas tentang inovasi pembelajaran pendidikan agama islam berbasis blended learning yaitu perpaduan pembelajaran tatap muka dengan menggunakan cooperative learning dan keterbatasan dalam pembelajaran tatap muka tersebut digunakan penggunakan pembelajaran e-learning berikut pengembangannya sehingga menjadi suatu tipe pembelajaran baru yang lebih efektif, efisien dan menarik bagi siswa. Pendekatan untuk mengkombinasikan kegiatan tatap muka di kelas dengan kegiatan berkelompok selama proses pembelajaran pendidikan agama islam dan penilaian berpasangan dapat disebut sebagai pendekatan blended cooperative e-learning (BCeL). Menurut (Nawangsari, 2010) BCeL dapat digunakan sebagai suatu alternatif jenis pembelajaran yang tidak hanya efektif, efisien, dan menarik sebagai sarana untuk menunjang learning community bagi siswa, karena dalam $B C e L$ selain terdapat interaksi guru dan interaksi muatan juga terdapat interaksi sosial yang mementingkan siswa dapat mempersepsikan diri mereka sebagai sebuah komunitas yang saling bergantung secara positif (positive interdependent).

\section{Metode Penelitian}

Dalam penelitian ini digunakan metode penelitian dan pengembangan yang merupakan bagian dalam merode kualitatif. Yang dimaksud dengan penelitian dan pengembangan atau research and development $(R \& D)$ adalah rangkaian proses atau langkah-langkah dalam rangka mengembangkan suatu produk baru atau menyempurnakan produk yang telah ada agar dapat dipertanggung jawabkan (Handoko, 2017). Dalam penelitian ini penulis akan mengembangkan perangkat lunak dalam pembelajaran yaitu metode pembelajaran pendidikan agama islam melalui blended cooperative learning. Adapun langkah-langkahnya adalah:

1. Pengumplan informasi awal

2. Perencanaan

3. Pengembangan produk awal

4. Uji coba awal

5. Revisi produk

6. Uji coba lapangan

7. Revisi produk

Tempat Penelitian Penelitian ini bertempat di perguruan muhammadiyah cabang senen jakarta, Jl. Kali baru barat No.52 D bungur senen jakarta pusat.

\section{Hasil dan Pembahasan}

\section{Blended Cooperative e Learning}


Pembelajaran pendidikan agama islam yang cocok dan akan dikembangkan di perguruan muhammadiyah cabang senen jakarta adalah metode blended cooperative e-learning atau disingkat $B C e L$. Kerangka teori $B C e \mathrm{~L}$ ini dibangun berdasarkan pandangan dari beberapa teori yang mengkerangkai cooperative learning. Dalam $B C e L$ dipadukan tiga jenis interaksi yang meliputi interaksi sosial, inetraksi muatan, dan interaksi guru. Penjelasan adalah berikut:

1. Tipe interaksi pertama adalah dengan guru yang menjadi fasilitasor active learning dan interaksi tatap muka yang terjadi pada suatu setting sosial. Akan tetapi gurulah yang merancang dan mengelola urut-urutan pembelajaran dan menyeleksi media yang tepat sebelum berinteraksi dengan siswa. Selanjutnya guru menggunakan e-learning untuk meakukan pembelajaran jarak jauh dan pengumpulan tugas serta komunikasi secara online. Siswa dapat berdiskusi dengan siswa lain dan dengan siswa dapat berdiskusi dengan siswa lainnya dengan guru pada waktu yang bersamaan sehingga akan terjadi komunikasi interpersonal dan feedback. Pembelajaran dilakukan melalui portal sekolah, google classroom dan Whatsapp.

2. Interaksi kedua adalah dengan muatan interaksi ini menjembatani interaksi kognitif dengan konsep konsep dan keterampilan yang termuat dalam modul pembelajaran. Modul tersebut disertai dengan petunjuk penggunaan dan mind mapping setap topik sehingga tujuan pembelajaran tergambar dengan jelas. Selain modul juga digunakan lembar kerja siswa yang diambil secara berkala oleh siswa yang tidak memiliki perangkat telepon pintar atau akses internet, setelah dikerjakan di rumah sesuai dengan waktu yang telah ditentukan, lalu dikumpulkan setiap pekan ke sekolah.

3. Terakhir, interaksi sosial dimaksudkan senbagai kemampuan pembelajar (siswa) untuk mempersepsikan diri mereka sebagai sebuah komunitas yang saling bergantung secara positif (positive interdependent, cooperation). Interaksi yang demikian itu dapat terjadi di keseluruhan proses pembelajaran karena mereka engerjakan tgas-tugasyang menuntut kerjasama. Sebagaimana diketahui dimensi interaksi (diskursus social). Makna ini kemudian dibagai diantara anggota-anggota kelompok yang ikut membangun pengetahuan bersama melalui tanggapan antar mereka sendiri. Ini sudah merupakan pencapaian level kognitif yang tinggi (Aviv, 2000).

Selama ini metode yang digunakan dalam pembelajaran pendidikan agama islam di perguruan muhammadiyah cabang senen jakarta adalah metode langsung dengan berorientasi pada ceramah ataupun power point. Metode ini berdasarkan survey yang disebar ke peserta didik dirasakan membosankan dan kurang inovatif. Oleh karena itu perlu inovasi pembelajaran yang aktif interaktif serta menyenangkan dalam pembelajaran pendidikan agama islam dan inovasi itu adalah blended cooperative e learning. Dari hasil uji coba produk di dapati bahwa keaktifan serta pemahaman siswa terhadap pembelajaran pendidikan agama islam menjadi meningkat. Sebelum uji coba metode blended cooperative e-learning nilai rata-rata pelajaran pendidikan 
agama islam adalah 75, setelah uji coba metode blended cooperative $e$ learning nilai rata-rata mereka menjadi 78. Disamping itu interaksi dan kerjasama mereka menjadi lebih solid dan padu.

\section{Kesimpulan}

Perpaduan antara pendekatan pembelajaran cooperative learning dan blended learning tidak saja hanya membekali siswa kemampuan memahami materi, namun lebih dari itu dapat meningkatkan kemampuan komunikasi dan keterampilan interpersonal, pemecahan masalah, analisis kritis dan keterampilan lain yang dibutuhkan oleh siswa. Dengan kemudahan teknologi, keterbatasan pertemuan di kelas dapat dipecahkan dengan blended learning. Blended learning tidaklah sesederhana sebagai sebuah sebuah kombinasi pengajaran langsung (direct learning) dan pengajaran online tapi lebih daripada itu sebagai elemen dari interaksi sosial, ketika para siswa diperlukan untuk lebih sering bekerjasama secara online, mereka saling berbagi permasalahan secara umum pada tingkatan yang beragam, mereka kemudian menciptakan komunitas "penyelesaian masalah"mereka sendiri. Dengan blended cooperative e-learning pembelajaran pendidikan agama islam yang dulu monoton dan searah akan menjadi menarik dan interaktif, semua terlibat dalam pembelajaran yang menyenangkan.

\section{BIBLIOGRAFI}

Aviv. (2000, November). Decision support system for the management of an agile supply chain. Google Patents.

Bakri, Wahyuddin. (2020). Bunga Rampai Pandemi.

Handoko, Prio. (2017). Sistem Kendali Perangkat Elektronika Monolitik Berbasis Arduino Uno R3. Prosiding Semnastek.

Harding, Ansie, Kaczynski, Dan, \& Wood, Leigh. (2012). Evaluation of blended learning: analysis of qualitative data. Proceedings of The Australian Conference on Science and Mathematics Education (Formerly UniServe Science Conference), 11.

Juliani, Henny. (2020). Analisis Yuridis Kebijakan Keuangan Negara Dalam Penanganan Pandemi Covid-19 Melalui Peraturan Pemerintah Pengganti UndangUndang Nomor 1 Tahun 2020. Administrative Law \& Governance Journal, 3(2), 329-348.

Nawangsari, Dyah. (2010). Urgensi Inovasi dalam Sistem Pendidikan. Jurnal Falasifa, $1(1)$.

Pujilestari, Yulita. (2020). Dampak Positif Pembelajaran Online Dalam Sistem Pendidikan Indonesia Pasca Pandemi Covid-19. 'ADALAH, 4(1). 
Rusdiana, Ahmad, Sulhan, Moh, Arifin, Isep Zaenal, \& Kamaludin, Undang Ahmad. (2020). Penerapan model POE2WE berbasis blended learning google classroom pada pembelajaran masa WFH pandemic Covid-19.

Saefudin, Asep. (2008). Perkembangan Teknologi Komunikasi: Perspektif Komunikasi Peradaban. Mediator: Jurnal Komunikasi, 9(2), 383-392.

Sanjaya, Ridwan. (2020). 21 Refleksi Pembelajaran Daring di Masa Darurat. SCU Knowledge Media.

Setiani, Dina Dwi, Nivanty, Hanien, Lutfiah, Wardah, \& Rahmawati, Lilik. (2020). Fintech syariah: manfaat dan problematika penerapan pada UMKM. Jurnal Masharif Al-Syariah: Jurnal Ekonomi Dan Perbankan Syariah, 5(1).

Siahaan, Matdio. (2020). Dampak Pandemi Covid-19 Terhadap Dunia Pendidikan. Dampak Pandemi Covid-19 Terhadap Dunia Pendidikan, 20(2).

Simarmata, Janner, Chaerul, Muhammad, Mukti, Retno Cahya, Purba, Deddy Wahyudin, Tamrin, Andi Febriana, Jamaludin, Jamaludin, Suhelayanti, Suhelayanti, Watrianthos, Ronal, Sahabuddin, Andi Arfan, \& Meganingratna, Andi. (2020). Teknologi Informasi: Aplikasi dan Penerapannya. Yayasan Kita Menulis.

Suhendro, Eko. (2020). Strategi Pembelajaran Pendidikan Anak Usia Dini di Masa Pandemi Covid-19. Golden Age: Jurnal Ilmiah Tumbuh Kembang Anak Usia Dini, 5(3), 133-140.

Syaparuddin, Syaparuddin, Meldianus, Meldianus, \& Elihami, Elihami. (2020). Strategi pembelajaran aktif dalam meningkatkan motivasi belajar pkn peserta didik. Mahaguru: Jurnal Pendidikan Guru Sekolah Dasar, 1(1), 30-41.

Wahidin, Unang. (2018). Implementasi Literasi Media dalam Proses Pembelajaran Pendidikan Agama Islam dan Budi Pekerti. Edukasi Islami: Jurnal Pendidikan Islam, 7(02), 229-244.

Yaumi, Muhammad. (2017). Prinsip-prinsip desain pembelajaran: Disesuaikan dengan kurikulum 2013 edisi Kedua. Kencana.

Yunus, Nur Rohim, \& Rezki, Annissa. (2020). Kebijakan Pemberlakuan Lock Down Sebagai Antisipasi Penyebaran Corona Virus Covid-19. Salam: Jurnal Sosial Dan Budaya Syar-I, 7(3), 227-238. 